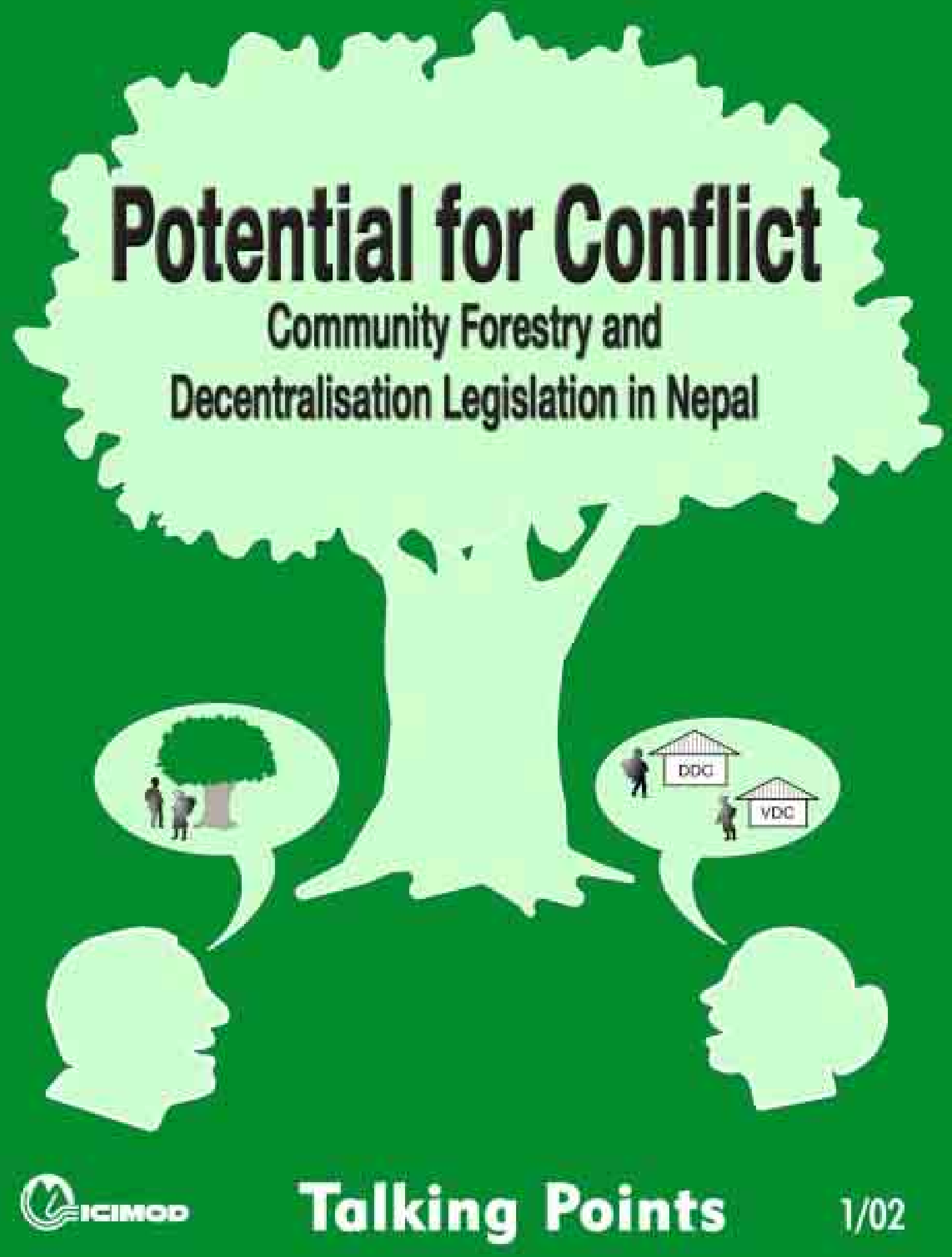




\section{about ICIMOD}

The International Centre for Integrated Mountain Development (ICIMOD)is an international organisation devoted to development of the Hindu Kush-Himalayan region covering all or parts of eight sovereign states. Afghanistan $\square$, Bangladesh - , Bhutan China India Myanmar Nepal 5 , and Pakistan The Centre is located in Kathmandu, Nepal. The primary objective of the Centre is to promote the development of an economically and environmentally sound mountain ecosystem and to improve the living standards of mountain populations.

'Talking Points' is a new series from ICIMOD that will contain short presentations of topical, controversial, or problematic themes, where general consensus has not yet been reached or where action may be appropriate. They are intended to stimulate thought and discussion, their contents should not be seen as definitive statements. 


\title{
Potential for Conflict \\ Community Forestry and Decentralisation Legislation in Nepal
}

\author{
Narayan Belbase \\ and \\ Dhrubesh Chandra Regmi
}

February 2002

International Centre for Integrated Mountain Development (ICIMOD)

Kathmandu, Nepal 


\section{Copyright $\odot 2002$}

International Centre for Integrated Mountain Development

All rights reserved

\section{Published by}

International Centre for Integrated Mountain Development

G.P.O. Box 3226

Kathmandu, Nepal

\section{ISBN 9291154601}

\section{Editorial Team}

\section{A.B. Murray Shrestha (Editor)}

Rosemary Thapa (Consultant Editor)

Dharma R. Maharjan (Technical Support and Layout)

\section{Printed and bound in Nepal by}

Quality Printers Pvt. Ltd

Kathmandu

The views and interpretations in this paper are those of the author(s). They are not attributable to the International Centre for Integrated Mountain Development (ICIMOD) and do not imply the expression of any opinion concerning the legal status of any country, territory, city or area of its authorities, or concerning the delimitation of its frontiers or boundaries. 


\section{Preface}

The way in which Nepal's forests and other natural resources are managed is profoundly important for the well being of the people, given that a large portion of the population depend on the forests in their day-to-day life. It is now well recognised, that to ensure sustainable forest management the people most closely concerned - the forest users - must be actively involved and able to take decisions, carry out tasks, and also benefit. There has been progressive legislation in Nepal over the past decade designed to achieve this, in particular the Forest Act of 1993 with its focus on community forestry and handing over forest to user groups. However, 'decentralisation', the devolution of powers to local communities, is not just important for forestry, it is an approach being used for a whole range of management tasks in communities. The Local Self-Governance Act of 1998, which replaced three earlier local government acts, aimed to involve local people to the maximum extent in the development process. Under this act, local elected government bodies have powers and functions (and responsibilities) over eleven broad areas including such things agriculture, irrigation, soil erosion management - and 'forest and environment'.

The inclusion of local level authority over forests in different ways in there two acts opens up an area of contradiction and is a potential source of conflict. There are similar contradictions in the provisions of other acts like the Nepal Mines Act 1966 and the Soil and Watershed Conservation Act 1982, although these are possibly not as grave as the contradictions between the Forestry Act and the Local Self Governance Act.

ICIMOD, through its Natural Resources Division, has taken an active interest over the past years in the introduction of community forestry in various forms in countries across the Hindu Kush-Himaklayan region, and its contribution to enabling more sustainable use and management of natural resources. We have endeavoured to collect and disseminate information about different practices and to bring different groups together to exchange views and to develop partnerships that contribute to the success of community forestry. Community forestry has been particularly successful in Nepal, and we are concerned that this success should not be threatened by conflicts that simply arise form a lack of clarity in the legal provisions. For this reason, we are very happy to be able to publish this paper by two distinguished experts on environmental law, with a clear academically precise summary of the situation, and suggestions on the changes needed to ensure clarity in the provisions. It is a thought provoking document, and we hope it will stimulate discussion -and action - that will help facilitate the smooth working of the community forestry programme in Nepal. 


\section{Executive Summary}

Over the past decade, the Government of Nepal has passed progressive legislation regarding decentralisation and the devolution of powers to local communities. These include the Forest Act of 1993 and the Local Self Governance Act of 1998 (LSGA). The following paper analyses the provisions of these Acts regarding the management and development of forest resources. It also considers legal provisions pertaining to other natural resources. In addition, the difficulties inherent in each Act and overlapping provisions between them are examined.

Community forestry, through which forest resources are developed and managed with the active participation of local forest user groups (FUGs), forms a major part of the Forest Act. However, in giving certain powers over forests and the environment to village development committees (VDCs), the lowest tier of local government, the LSGA opens up an area of contradiction and possibly conflict between these two institutions. VDCs, as elected bodies, have a broader mandate than FUGs, and could potentially seek to manage their own community forests or have local FUGs under their own control.

The paper makes several recommendations on how to improve the community forestry programme, and suggests the development of a legal framework to reduce the adverse effects of contradictions in sectoral legislation. The authors emphasise the need for consultation and serious dialogue between FUGs and local, elected institutions to address the concerns of local government, at the same time as maintaining the autonomy, powers, and functions of the FUGs. 


\section{Acknowledgements}

The authors wish to express their gratitude to Dr. Pralhad Yonzon, Dr. K.R. Panday, Dr. K.K. Panday, Mr. Krishna B. Shrestha, Mr. Hari P. Neupane, Mr. Khagendra Sigdel, Mr. Nick Roche and Mr. Anupam Bhatia for the valuable suggestions so generously provided during the preparation of this paper. 


\title{
Acronyms and Abbreviations
}

\author{
BZMR Buffer Zone Management Regulations \\ $\mathrm{CBO}$ community based organisation \\ $\mathrm{CF} \quad$ community forest \\ CFUG community forest user group \\ DC district council \\ DDC district development committee \\ DDCA District Development Committee Act \\ DFO district forest officer \\ DLSG decentralisation and local self governance \\ DoF Department of Forests \\ DSCWM Department of Soil Conservation and Watershed Management \\ DWRC district water resources committee \\ DWSO district water supply office \\ FA Forest Act \\ FUG forest user group \\ HLDCC High Level Decentralisation Coordination Committee \\ HMGN His Majesty's Government of Nepal \\ LSGA Local Self-Governance Act \\ MFSC Ministry of Forest and Soil Conservation \\ MPFS Master Plan for the Forestry Sector \\ NGO non-governmental organisation \\ NPC National Planning Commission \\ NPWCA National Parks and Wildlife Conservation Act \\ SWCA Soil and Watershed Conservation Act \\ UA users association \\ UC users committee \\ UG user group \\ VC village council \\ VDC village development committee \\ VDCA Village Development Committee Act \\ WCO watershed conservation officer \\ WRA Water Resources Act \\ WRR Water Resources Regulations \\ WUA water users association
}




\section{Contents}

one: historical overview

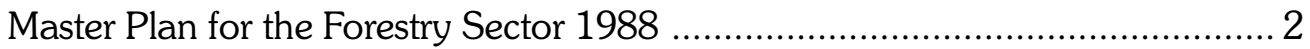

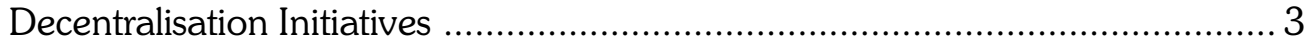

two: the legal status of forest user groups ................................................ 5

Procedure for Handing Over a Community Forest ........................................ 5

Formation and Registration of Forest User Groups ........................................ 6

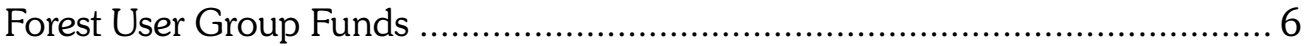

Work Plan (Operational Plan) for Community Forests .................................... 7

Activities Prohibited in the Community Forest .................................................. 7

Collection, Sale and Distribution of Forest Products ........................................ 8

Taking Back the Community Forest ............................................................ 8

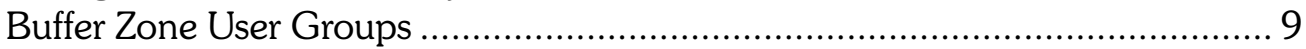

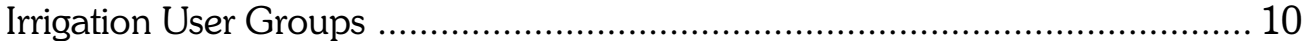

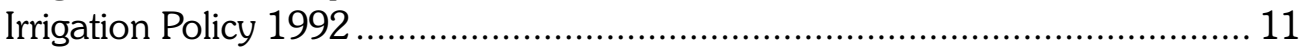

three: decentralisation and the status of local government ................... 13

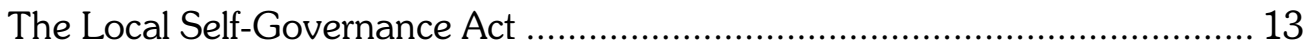

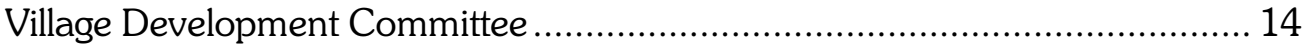

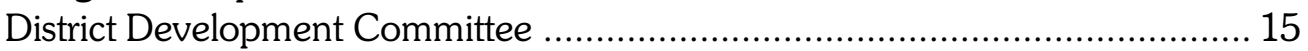

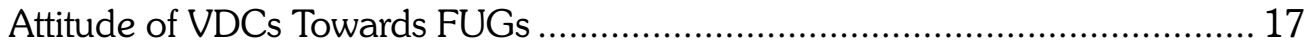

four: contradictions and conflicts .................................................... 19

Contradictions within Forestry Legislation ................................................. 19

Contradictions Between Forestry and Decentralisation Laws ........................ 22

Contradictions Between the Forest Act and Other Laws ................................ 25

five: complementarities and gaps ................................................... 29

six: looking towards the future ........................................................ 33

seven: bibliography ............................................................................... 37 